\title{
Local Representations of Evenkiness and Managing Identities among Evenki Adolescents in Buryatia
}

\author{
Svetlana Huusko \\ University of Oulu, Finland \\ svetlanaahuusko@gmail.com
}

\begin{abstract}
This article explores Evenki adolescents' response to Russian representations of indigeneity in Buryatia (Russia) to gain an understanding of how Indigenous adolescents negotiate their space and identity in the context of local representations of Evenkiness. I position indigenous identity within social interactions. In Russia, these relations are not only political in nature, but also are located within a set of institutionally sanctioned dominant discourses and stereotypes based on them. The results show that Evenki adolescents in Nizhneangarsk often employ a strategy of managing ethnic identities, which could be viewed as a product of cultural-political context, formed during the Soviet Union and reinforced by modern Russian politics. It is a product of marginalisation and manifestation of assimilation of the Evenkis.
\end{abstract}

\section{Keywords}

Ethnic identity - indigenous - adolescents - Evenkis - stigma - marginalisation

\section{Introduction}

If a person is an Evenki, people [in Nizhneangarsk] think they are drunk, poor. We may be not ridiculed, but we are not taken seriously.

We lost our dignity.... We are not proud to be the Evenkis....

These two passages from conversations with Evenki informants capture the picture of Evenki adolescents not only living in a world of stereotypes and 
prejudice, but also internalising these stereotypes, and in some cases trying to avoid them by distancing themselves from being recognised as Evenki.

This article focuses on the existing representation of Russianness and Evenkiness in a local community in Nizhneangarsk, Severobaikalskii district of the Republic of Buryatia, Russia, where I conducted fieldwork. According to Russian Census (2010), out of a total of 5046 people in Nizhneangarsk (the administrative centre of Severobaikalskii district), there were 4364 Russians, 151 Buryat, 48 Tatar, 72 Ukrainians and 226 (around 5.18 per cent) Evenkis. Using participant observation and face-to-face interviewing as my main methods, I show how local representations of Evenkiness lead to stigmatised identities among Evenki adolescents in Nizhneangarsk. I argue that these representations both construct and reflect the way that indigenous identities are developed and perceived.

Evenkis are one of the Tungus-speaking groups in the Russian North. The Tungus group is often referred to as Western Tungus (Evenki) and Northern Tungus (Eveni), or the Northern Tungus (the Eveni or Lamut) and the Southern Tungus (the Evenki), populating the areas closer to the north of Lake Baykal (Ulturgasheva 2012: 7). In this research, the fieldwork was undertaken in northern Transbaikalia.

The Evenkis are officially recognised in Russia as one of 'the indigenous small-numbered peoples of the North, Siberia and the Far East'. According to Russian federal legislation, such Indigenous Peoples are 'peoples living in the territories of the North, Siberia and the Far East in the territories of traditional settlement of their ancestors, preserving a traditional way of life and a traditional economic system and economic activities, numbering fewer than 50,000 persons, and recognizing themselves as independent ethnic communities' (RF 2000a). The definition is deeply rooted in the representation of tradition, which is linked to the ancestors' past and its preservation or continuity. Based on this definition, the government recognises 47 ethnic groups as Indigenous Small-Numbered Peoples of the Russian Federation and maps their territories of residence (RF 200ob). In Russia, in spite of the recognition of the right of indigenous peoples to define themselves (RF Constitution, Article 69 2009), the state defines which groups are indigenous, who can be identified as a member of this group and what kind of lifestyle they have to lead to be indigenous. Ideas about the primordial nature of indigenous culture and ethnicity create a situation where many people, and especially adolescents, equate their own culture to 'prehistoric' traditions, which have been long influenced by centuries of colonisation, alienation, and violence in Russia. This assumption of the ontological nature of 'culture', or the existence of pure cultural form, makes the 
indigenous culture irrelevant for many Evenki adolescents today in Buryatia and leads them to think that they are not a part of the 'real' culture.

In the seventeenth century in the territory of the contemporary Severobaikalskii district, the Evenkis were engaged in hunting and fishing, maintaining domesticated reindeer for transportation, or larger-scale reindeer breeding (Vasilevich \& Smolyak 1964: 644). The reindeer Evenkis, or orochons, were organised into patriarchal clans, shifting their camps with herds of cattle and horses from winter to summer pastures (Shubin 2001; Vasilevich \& Smolyak 1964).

The first Russian colonists began to invade northern Transbaikalia in the mid seventeenth century. The Cossacks were the backbone of Russian expansion in Siberia, hired by the state to make alliances with Siberian tribes, including the Evenkis, and collect an obligatory annual fur tribute, yasak (Bisher 2006). Northern Transbaikalia was home to the most valuable of the sable species, the dark Barguzin sable that ensured the continued importance of Siberia in the world fur market. By the late 160os, a network of fortresses, trading posts and wintering huts was established to extract tribute and furs and control trade in northern Transbaikalia (Fondahl 1998: 40). To ensure payment of tribute to the Russian state, the Cossacks established fortresses (ostrog), forced native leaders to take oaths guaranteeing payment and frequently took hostages from the clan leaders. Jamie Bisher (2006: 10) wrote: 'during the infancy of Siberia's settlements, flogging, lip- and nose-slitting and burial alive were still officially sanctioned punishment among the Cossacks.' He pointed at cases of enslavement of natives, forced labour, rape, incidents of mass murder, kidnapping and trading in indigenous women. The violent character of the tribute collection was also underlined by Evenki author Aleksandr Shubin in his work Baikal Evenkis (2001). The outbreaks of smallpox, syphilis and influenza which followed the establishment of the network led to a significantly decreased population of the Evenkis and consequently to merging of isolated clans, and some Evenkis had to look for paid jobs in other clans or Russian settlements (Bisher 2006; Landers 2011).

Eventually, the Evenkis began forging strong commercial ties with both Russians and Buryats through a specialised exchange and by the 1700 s had become active participants in the Siberian fur trade. These commercial pursuits eroded the traditional subsistence economy, linking the Evenkis to widespread markets and unsettling many social institutions, such as the clan system (Vasilevich \& Smolyak 1964).

Consequently, the Russian state claimed the land in Siberia as its own. Native Siberians did not own the land, nor had they control over the extraction of its mineral resources. That situation aggravated conflicts between Evenkis 
and Russians. In 1822, Mikhail Speranskii, the Russian Tsar's advisor, to protect the further provision of fur in the face of sable over-hunting and danger of its extinction advanced a 'Statute on the Administration of Aliens in Siberia'. This law ensured that settled 'aliens' (native people), inorodtsi, had the same rights as Russians. For wandering natives (including nomadic Evenki reindeer herders), a statute guaranteed allotments of land on which they depended. These allotments guaranteed rights of occupancy, usage and administration of state-owned land. Other groups had to ask permission to lease those allotted territories. The allotments were distributed to native clans, established by the same statute, rather than to the existing clans. Some of the existing clans were merged. For administrative purposes, the state identified the 'elders' who were elected by the Russian supervision, to ensure that those elected were the most reliable and responsive to state needs (Fondahl 1998).

In the 1800 s Tsarist Russia sought not only to expand the boundaries of the Russian empire, but also to create the majority of the ethnically Russian population on the outskirts of the empire, which would become the demographical basis of state integrity (Remnev \& Suvorova 2010). As Remnev and Suvorova (2010: 22) underlined, the state considered Russian colonisation not only as a means to eliminate tribal differences, but also to oppose 'cultural force of the Russian people' to 'the pressure of the yellow mass in Siberia to protect the integrity of the state on its outskirts'.

The church played a major role in the colonisation of Siberia. The purpose was to create a traditionally Russian Siberia, where Orthodox Russian people lived (Remnev \& Suvorova 2010: 34). In Dushkachan village, the meetingplace of the Kindigir Evenki clan in northern Transbaikalia, construction of the church was begun in 1839 (Severobaikalskii Municipal District official website). Tsarist Russia sought to impose Christianity on the Evenkis through missionary work. Christianisation of the Evenkis commenced in the seventeenth century and by the end of the nineteenth, in the territory of the contemporary Severo-Baikalskii district, most of the Evenkis were converted to the Christianity. However, the process was often formal, and the Evenkis also largely retained their own beliefs, rituals and shamans (Shubin 2007; Vasilevich \& Smolyak 1964).

The role of the church was to create not only spiritually but also politically heterogeneous Russian space through the construction of chapels, churches, monasteries and cathedral churches. It was important to broadcast the symbolic value of the Orthodox Church to new places, which led to the sacralisation of new spaces in Siberia. Thus traditions of Russian church architecture helped to formulate ethnocultural identity by the transmission of the names and concepts of the Russian Orthodox Church and Russian culture to a new 
space. New popular Russian Siberian heroes, such as first Russian colonists Ermak or Dezhnev, were incorporated in the minds of Siberian Natives. The building of new Orthodox churches, establishing monuments to fallen heroes, celebrating church and state holidays and anniversaries of joining to Russia became an entrenched demonstration of belonging to Russia, or Russianness, that was emphasised in the preaching of the priests, proclaimed by local governors, promoted by public figures and historians. Local museums, public history readings, and commemorative mass editions were intended to serve the same purposes of incorporation of Native Siberians into the political and spiritual body of Russia (Remnev \& Suvorova 2010).

Before the Communist Revolution (1917), for the reindeer herding Evenkis, a fundamental organisational unit was a jointly migrating group of blood-related families (Shubin 2007). However, with the ravages of introduced disease, often one migrating unit incorporated more than one clan (Fondahl 1998). Those Evenkis who lived near gold mines and accessible sable grounds suffered total land dispossession and were forced to work for state needs or relocate further north.

However, it was the Communist Revolution and Soviet 'nation-building' policy that brought more hegemonic changes to the Evenki lifestyle. The master-plan of the Soviet state was that the indigenous peoples should bypass the slaveholding, feudal and capitalist stages of development and leap directly from primitive communal society to socialism (Grant 1993; Slezkine 1994). Such a passage from 'tradition' to 'modernity' required 'modernisation and industrialisation within the Marxist-Leninist norms of social, economic, and political behaviour' (Bartels \& Bartels 1995: 5). Thus the Soviet Union took Marxist ideology and introduced a programme of massive industrialisation and consolidation on political, economic and cultural scales. Aiming at the integration of the Evenkis into the social, political, and economic body of the state, the Soviet government began total collectivisation of Evenki economic activities in 1929 .

Collectivisation proceeded with settlement and relocation of the Evenkis and confiscation of the reindeer, about half of which were lost due to carelessness towards confiscated livestock. Thus, according to Evenki Native researcher Aleksandr Shubin (2001: 87-8), in 1934, in the Buryat Republic, reindeer numbers decreased by 68.8 per cent. New settlements were established to serve as centres of collective activities. The locations of these new settlements were chosen for easier access. Begun in the 1940 s and recommenced in the 1950s, the politics of consolidation of collective farms led to the relocation of Evenkis to larger villages, which could be hundreds of kilometres away from their traditional ancestral lands. In the 1970s, many Evenkis lost the right to 
hunt according to the new Soviet policy; reindeer husbandry was considered an irrational activity and started slowly to diminish in northern Transbaikalia (Fondahl 1998). For Evenkis, the consequences of collectivisation were the loss of subsistence activities, dispossession of indigenous hunting grounds, social disorganisation, ruptured family ties, the introduction of new professional structures in which in Severo-Baikalskii district most of the Evenkis could only take the lower wage positions, and unemployment (Fondahl 1998).

Soviet efforts to harness the rich natural resources of Siberia into the use of the national economy weakened Evenkis' control of their homelands. It also brought growing numbers of newcomers to Evenki territory. Between the 1950 a and the 1980s, Russians, Ukrainians, Baltic people and other ethnicities poured into Siberia as a result of state-sponsored industrialisation of the area. According to the first Soviet Census in 1926, the population of Severobaikalskii aboriginal district (Severobaikalskii tuzemnii raion) had been only 2644 (USSR Census 1926). In 1970 the population of Severobaikalskii aimak had not yet changed dramatically and was only 5824 (USSR Census 1970). By 1989, it had rocketed to 40,213, mainly due to the construction of the Baikal-Amur (Railway) Main Line (BAм, 1974-1989) and, to a lesser degree, geological exploration (1950s-1990s) and mining operations (Russian Census 1989). The next Russian census was after the collapse of the UsSR; the construction of BAM had been completed, and the population of the district decreased to 16,446 in 2002 (Russian Census 2002). The land base used by the Evenki decreased, and most Natives had to abandon reindeer herding and other traditional livelihoods to work at the Baikal-Amur railway, various mining and construction sites and collective state farms (Russ. kolkhoz) (Fondahl 1998).

It was designed not only to impose Communist ideals on Native communities; it also became a strategy for the government to examine the loyalty and political reliability of Indigenous groups and individuals (Davydov 2008: 147). Consolidation, or creating a new national identity, was considered a necessary step towards a new 'modern' socialist society. It was crucial to overcome such primitiveness and lift the Evenkis and the other Siberian Natives, such as Buryat, Chukchi, Sakha (also called Yakut), Soyot, Tuvan and others, to the cultural and intellectual level of ethnic Russians. The Soviet civilising mission was constructed on a rigid ethnic hierarchy which portrayed the Russians as an 'older brother' of the Indigenous peoples, far above them on the evolutionary ladder and with an obligation to guide the Natives toward a socialist civilisation, the pinnacle of human evolution. Thus, from the 1920s onwards, the Soviet authorities also expended considerable energy in the cultural transformation of the Evenkis and their Native neighbours, Buryat and Soyot. According to the official Soviet view, the Indigenous peoples were 'culturally 
primitive', and their life was characterised by 'backwardness' and 'inability to conceive even the elements of culture' (Kozlov et al. 2007). In the Bolsheviks' ideology, the 'backwardness manifested itself in traditional culture, worldview, sacral and profane practices, and the ancient social structure of nomadic society' (Bashkuev 2013: 130).

The nation-building goal was accompanied by the development of growing awareness of a need for a common history and culture. Better execution of the nation-building goals was possible through a common educational system of citizens, including indigenous populations (Bartels \& Bartels 1995). Accordingly, the Communist rulers envisaged education, especially residential schools, as a critical element in cultural conversion and nation building, aimed at integrating the Evenkis into the Soviet society and rooting out their lifestyle (Bloch 2004; Ulturgasheva 2012).

In Severo-Baikalskii district residential schooling was introduced to Evenki children in 1925, where the language of instruction was Russian. Initially these schools were meant for nomadic peoples; however, subsequently, residential schooling became mandatory for all children of native peoples of the north (Arefiev 2014). Consequently, the Evenkis lost their right to teach their children and transmit traditional knowledge and spiritual beliefs to new generations. Instead, schools sought to indoctrinate the children with a new science-based Communist worldview, according to which the nomadic lifestyle was considered backward. In Nizhneangarsk, even nowadays, the local museum effectively constructs an image of an Evenki as a primitive creature driven by primitive beliefs and Nature. The museum explains the animistic and polytheistic view of Nature by the Evenkis' primitiveness as opposite to contemporary scientific explanations. Moreover, the museum ridicules the Evenki way of living prior to the Revolution: ' $\mathrm{t}$ ] he natives lived the most pauper and miserable life, had no idea of the bath, the medicine, the school, etc.' (Author's fieldwork notes and photographs, 2012 and 2016). By portraying the Evenki 'traditional' way of living as 'primitive' and the new Soviet way of life as 'civilised', the residential schooling invented a choice for its students to become a part of modern and advanced society, or to stay in the past. In educational settings, learning to read and write simultaneously went with learning about patriotism, state war and political leaders and heroes, the nature of new social institutions. At school, Indigenous children learned the new policies and social norms, including how to behave in public spaces, the virtues of daily hygiene and the importance of agriculture over fishing and foraging (Grant 1993: 233).

At residential schools, Evenki children were fully economically supported, politically and morally guided by the state. Separated from their families, many Evenkis lost their language, much of their cultural knowledge of spiritual 
beliefs, their sense of belonging to a family or kinship network, and how to function as a family in the way of being able not only to pass on their indigenous identities to the next generation, but also to socialise the next generation. In Severobaikalskii district, Evenki children are dispersed in Russian schools. In the district, there is only one school where some Evenki language and some elements of the Evenki material traditional knowledge (handcraft) are taught. However, in Nizhneangarsk, the school is a typical Russian upper-secondary school, where there is no Evenki language or cultural teaching. Most of the students are ethnically Russian. The school does not invite Evenki elders to school to speak about Evenki culture. In the website of Severobaikalskii district, the school represented itself as 'unified informational, educational space for the proper and effective education of students to build the identity as a citizen of their country, who are able successfully to realise their potential in society'. Thus the mission does not refer to Evenki culture at all, but rather alludes to Russian national identity. Moreover, the employees of the Evenki Children Cultural Centre expressed a regret that school students never come with the fieldtrips to get to know the Evenki traditions (Author's fieldwork notes, 2016). At the same time, every year school students make fieldtrips to Severobaikalskii Museum of Local History, whose mission is in line with that of the school. According to its website, the museum aims at raising respect among children for the historical objects and heroic glory of Russia, broadening their horizons and increasing pupils' and youth's knowledge in the fields of history, culture and geography (Severobaikalskii Municipal District Official Website). Evenki social knowledge, religious, economic, communal and kinship institutions were replaced by first Russian, then Soviet institutions. The decades of residential indigenous schooling and paternal policy towards Siberian Natives brought the inevitable dependence of the Evenkis on institutional support.

Native religious rites and ceremonies, which could be seen as traditional forms of psychotherapeutic remedy, were often eliminated. The failure of the family to provide 'social, psychological, and moral protections for its members', lack of guides and orienting points', the loss of goal in life, 'the feeling of irrelevance in the changing world', and the feeling of powerlessness in their own life engendered a number of suicides, violent deaths, and such health problems as alcoholism and substance abuse among the native peoples of the north (Kozlov et al. 2007: 159). Another critical issue is the decrease of physical capital of communities after the collapse of the Soviet Union, which can be manifested by high levels of unemployment. Long-term unemployment and loss of hope for favourable changes also greatly contributed to the above-mentioned problems (Kozlov et al. 2007). 
Thus, the Soviet state has gradually blocked the Evenkis from the access to their traditional sources of subsistence and stripped them of their language and right to self-government (Bloch 2004; Kozlov et al. 2007). A minority on their homelands, the Evenkis became marginalised from decision making concerning local natural resources, communal politics and exercising their parental right to raise their children (Fondahl 1998). Today, in Severobaikalskii district, many Evenkis have to work seasonally outside their home communities and rely on the state's social benefits for a part of the year. This has given rise to powerful Russian stereotypes of the Evenkis as lazy, poor and living in 'broken' families. Indeed, an integral part of Russian and Soviet colonialism has been the creation of such 'othering' and racialising representations and stereotypes of the Evenkis. Not only have the processes of assimilation greatly eroded Evenki identity, but the results of the fieldwork show also that nowadays, while seeking to adapt to a Western environment, in Severobaikalskii district many Evenki adolescents often find little possibility for it. In this article, I show how racial discrimination and Russian representations of indigeneity affect Evenki adolescents' response to inequality and variations in their conceptions of who they are and what they want to become in life.

Since no culture can be free of outside influence, it is most important to look at the complexity of historically evolved cultural forms to understand what it really means to be an Evenki for many Evenki adolescents. I should underline here that it is not about the loss of culture, but rather about how a contemporary ethnic identity is emerging from the reality of colonisation, alienation, forced assimilation and the meeting and mixing of different cultural forms. Bhabha (2013) describes identity as a means by which people connect to the real or to the imagined as they perceive their personal and social world. In 1963, Erving Goffman pointed at the relatedness of self-identification to others, or, to another culture (Goffman 1984). Then it becomes clear that the ideas about them and us, our and their ways of life, could easily be placed at the core of racism and exclusion for minority children. Based on this framework, I look at an ethnic identity not as an inherent characteristic of an adolescent, but as flexible and negotiable, formed in a historically and geographically specific context through recognisable and repeatable behaviours.

The indigenous adolescents' identity formation cannot be separated from the relations that have been developed between colonial powers and indigenous communities. These relations have provided the context within which the identities have been constructed and reconstructed. I consider indigenous identity as an experience and knowledge system, socially and historically situated, reinforced by education and local representations of indigeneity, open to individual interpretation, negotiation, and renegotiation of its personal 
meaning and significance. Moreover, ethnic identity is located in social interactions. These relations are not only political in nature - that is, they are an object of contestation - but also they are located within a set of institutionally sanctioned dominant discourses and stereotypes based on them. The identities are constructed within public representations of 'Evenkiness', as opposed to representations of non-native ethnic group 'Russians'.

In my analysis of interethnic relationships, I use the concept of stigma, introduced by Erving Goffman (1984) to refer to an attribute that is deeply discrediting. He argues that stigma operates as both a representation and a creator of social meaning. Further developing this approach, Harald Eidheim (1982) described 'social stigma' in Lappish/Norwegian ethnic dichotomy terms; Bhabha (1994) placed 'mimicry' in a colonial context. More recently, Orna Sasson-Levy and Avi Shoshana (2013) applied Goffman's notion of passing out of the marked 'stigmatized' group (Mizrahim, Jews from North Africa and Middle Eastern countries), or 'acting white' (hishtaknezut), as mimicking the habitus of the dominant Ashkenazim (Jews of European origin) ethnic group in an Israeli context. In this article, I show that in Nizhneangarsk young Evenkis grow up in the middle of powerful and often pejorative colonial representations of their culture, community and history, ranging from museum exhibitions on native 'traditions' to racist jokes. As they construct their ethnic identities and sort out who they are and what they want to become in life, Evenki adolescents have constantly to negotiate with such representations and deal with the beliefs and expectations that the Russian majority has about them. Faced with discriminatory abuse based on racist stereotypes, some Evenki adolescents who lack facial features typically associated with northern Indigenous peoples can deny or hide their Evenki identity.

\section{Stigmatised Identities}

Identity building resources are provided not only by families, school books or academics, ${ }^{1}$ but also by everyday discourses, moving us into the power of stereotypes. From conversations with Evenkis and non-Evenki people in

1 Scientific sources usually equate ethnicities with a certain physical outlook. Accordingly, the Chair of Ethnography and Anthropology of Saint Petersburg State University describes the Evenkis as the Baikal anthropological type of the North Asian race with pronounced Mongoloid features (website of e-library 'Ethno-national communities of Russia: historicaldemographic and ethnocultural characteristics' available online: http://www.ethnos.nw.ru/ lib/data/141.html). 
Nizhneangarsk, there is a notable agreement not only on how Evenkis should look, but also on their behaviour patterns.

In this study, I use the term 'race', concerning the biological, or phenotypic, characteristics of an individual. The school textbook construct 'race's as fixed and objective way to define people pointing at the existence of the distinct biological types. Thus the school books provide students and teachers with the precise ready-made vocabulary and interpretation of the world and its social elements. Accordingly, the concept of 'race' was continually used by residents in Nizhneangarsk. I use the term 'ethnicity' when addressing the cultural characteristics of an individual as an ethnic group member. In Nizhneangarsk, ethnic and racial stratification is similar to that in numerous other societies, but with some distinctive features. The ethnic category 'Russian' is imprecise there and rather socially constructed, since it can refer to ethnic Russians, Ukrainians, Belarusians, or other non-indigenous European descendants. However, it is rather strongly associated with the phenotypic characteristics of the category 'Europeoid race'2 as opposed to the indigenous phenotype. The category 'Mongoloid race' is locally attributed to indigenous peoples, Buryat, Evenkis and Soyot. However, the phenotype characteristics of many Evenki adolescents are imprecise. Due to the history of meeting and mixing of the Evenkis and other populations, a non-negligible number of Evenki adolescents can identify themselves with both groups. While there are adolescents with pronounced physical characteristics, associated locally with the 'Asian' phenotype, in many cases it is difficult to determine the person's ethnic or racial affiliation.

In addition to phenotypic characteristics, the social categories 'Russian' and 'Evenki' are also in flux. When I conducted fieldwork in 2012 and 2016, I found that self-identification of Evenki adolescents is not fixed over time. Some of the teenagers changed their answers to questions of ethnic self-identification from one declaration to the next. Thus, in one case, one of the Evenki-registered

2 The concept of race is incorporated in the school curriculum and defined as a natural and objective way to categorise people. Thus 8th grade biology school textbooks for adolescents around 14 years old invite school students to learn differences between human races. While characterising people of 'Europeoid race' by 'light skin, straight or wavy, light brown or dark brown hair, gray, gray-green, brown-green or blue eyes wide open, moderately developed chin, a narrow protruding nose, not thick lips, well-developed facial hair in men', the school book distinguishes 'Mongoloids' by 'yellow or yellow-brown skin' and 'hard dark straight hair, broad flattened bony face, narrow and slightly slanted brown eyes with a fold of the upper eyelid in the inner corner of the eye (epicanthus), flat and rather broad nose, sparse facial and body hair' (Pasechnik 2010: 13). 
teenagers ${ }^{3}$ who identified herself as Evenki based on kinship during our first interview in 2012, in 2016 identified herself as Russian, based on racial phenotype. Another also changed his self-identification based on cultural characteristics, because in his opinion to be an Evenki a person should not only look Evenki, but also speak the Evenki language. There was also an opposite case when one of the teenagers, who previously identified himself ethnically as a Jew, in 2016 stated that he is Evenki, because 'I live on Evenki land; I am registered as an Evenki; I am used to the forest, the water, Lake Baikal; I go fishing' (Interview, Nizhneangarsk, 2016). It is also obvious from discussions with some Evenki adults, who stated that their self-understanding strengthened later in the course of their life, when memories of the past became more painful while the sense of shared experience, kinship and communal bonds and belonging became stronger (Author's fieldwork notes, 2016). Thus ethnic categories such as 'Russian' and 'Evenki' are not fixed and stable over time; they are in flux. In determining their ethnic identities, most Evenki adolescents did not speak about race, but rather underlined the importance of the ability to speak Evenki language, despite the fact that none of the interviewed Evenki adolescents could do so. As a whole, according to the information drawn from the Russian census, in 2010 the number of Evenki speakers was 4802 (Russian Census 2010), which means that only 13 per cent of the Evenkis speak their native language. The Evenki adolescents also underlined the importance of Evenki traditions that they usually equated with hunting, fishing and reindeer herding. Thus, a 13-year-old girl stated: 'I am Evenki, but sometimes I think that I am not.... Evenki are those who can tame reindeer, nomadise, and construct yurts' (Interview, Nizhneangarsk, 2016).

Even then, many Evenki adolescents in Nizhneangarsk feel ambivalent about the 'Asian' physical characteristics that the racial discourse, promoted in school books and their community, associates with the Evenkis. In contrast, many of them admire the 'Europeoid' features allegedly typical for Russians. During fieldwork, this came across clearly, when the adolescents talked about their ideas about beauty and ideal future spouses. For instance, Boris, a 17-yearold Evenki boy, told that he liked 'blondes'. According to him, 'it is important that a girl is beautiful inside and outside, for example, blonde' (Interview,

3 All of the interviewed adolescents were registered as Evenkis due to their parentage, or at least one of their parents is registered in their birth certificates as Evenki. To receive entitlements associated with 'the indigenous small-numbered peoples of North, Siberia and the Far East', Evenkis should have a document proving that they are officially registered as Evenki. Thus receiving the entitlements does not concern how individuals look or self-identify, but rather relies on the required document. 
Nizhneangarsk, December 2012). Such aesthetic preferences suggest that many Evenki adolescents in Nizhneangarsk feel the pressure of the racialised discourses surrounding them. Despite their claims that 'now all people look alike' (Interview, Nizhneangarsk, December 2012), they are keen observers of physical differences in the community and wish to distinguish themselves from those characteristics commonly associated with the Evenkis' supposed 'Mongoloid' racial background.

For the Evenkis the mainstream ideology has been largely ethnocentricthat white, Russian, Christian, Soviet is superior to their culture, reflected and furthered in schooling even nowadays according to the priorities of Nizhneangarsk school mission. Ethnocentrism becomes racist when some feel themselves to be superior as well as thrusting inferiority on to others. Thus, in this case, racial perceptions, attitudes towards the Evenkis and justifications of the civilising mission cannot be ignored. Perceived differences in phenotypic characteristics and behaviour are used to provide the basis for discrimination, establishing a civilised-primitive hierarchy in an ethnic relationship and supporting historically established hierarchies with Russians, Russian language and Russian culture at the top. Thus ethnic stratification exists in Nizhneangarsk. 'People here think that if they are Russians, they are better', one Evenki 15-yearold girl described the situation in Nizhneangarsk; she continued, 'Some people think that if a person is not Russian, there is no need to communicate with them' (Interview, Severobaikalskii District, December 2012). The historically established ethnic hierarchy marks the category 'Russian' or 'Europeoid race' as the sign of privilege.

On the contrary, the Evenki identity is often that stigmatised. Russian residents openly discuss the phenotypic characteristics of the Evenkis, often using offensive body language. Based on my conversations and interviews with Evenki and non-Evenki adolescents in Severobaikalskii district, most of them agree on ascribing the 'Asian' racial phenotype to the Evenkis. As one of the Evenkiregistered adolescents said, 'I am registered as Evenki, but I do not consider myself as Evenki. The Evenkis have narrower eyes and round faces, well they also have big cheeks' (Interview, Severobaikalskii district, 2016). Or, as another Evenki-registered adolescent stated, 'I identify Evenkis according to their appearances. They have narrow eyes and round faces' (Interview, Severobaikalskii district, 2016). Both adolescents came from mixed Russian-Evenki families and identified themselves as Russians. Other attributes of 'Evenkiness', supported by most non-Evenki residents of Severobaikalskii district, are that the Evenkis are usually poor and drunk. For instance, from conversations with residents: 
They [the Evenkis] are all drunkards there—men and women. FIELD NOTES, NIZHNEANGARSK, DECEMBER 2012

The local non-Evenki residents also described an Evenki woman as a person that indulges herself in promiscuous behaviour. At the same time, Russian residents commonly described an Evenki man as a violent person. An Evenki woman confided with regret that there are stereotypes that affect people's attitude towards the Evenkis:

When an Evenki man arrives at the hospital, the hospital personnel usually say: 'Again Evenkis got drunk and cut each other'.

The following passage from an interview with an Evenki woman from a nearby Evenki community, who often visits Nizhneangarsk, underlines how local stereotypes undermine the abilities of present-day Evenkis to engage in their political rights. She claims:

If a person is an Evenki, people [in Nizhneangarsk] think they are drunk, poor. We may be not ridiculed, but we are not taken seriously.

INTERVIEW, NEARBY EVENKI COMMUNITY, DECEMBER 2012

Apart from such attributes as 'single mothers' and 'broken families' that local people assign to Evenkis, the offensive remarks are usually about four themes: poverty, alcohol abuse and violence among the Evenkis in general, and the promiscuous behaviour of Evenki women. The remarks above are moderate; others could be much more offensive. Overall attitudes towards Evenkis reveal a mixture of subjective violence regarding personal prejudice and objective violence in terms of systemic prejudice.

As seen from the examples of the above remarks, apart from the perceived racial phenotypic differences, some residents claim that there are behavioural differences between ethnic Russians and Evenkis. Evenkis often face discriminatory abuse, which also can be based on moral judgements imposed by others. They are not only accused, but also expected to be ashamed of their acts, or just of being an Evenki. Moreover, they are expected to be grateful for being 'civilised', as becomes clear from conversations with residents in Nizhneangarsk:

The state gave them everything-education, housing. Workers of BAM built houses for them, very good houses. And what do they [Evenkis] do? 
They live surrounded by forest [the informant describes the Evenkis from a nearby Evenki community_-author], and they are not able to procure forest [the informant speaks here about forest logging (compared to buying or chopping firewood)—author]. They burn window frames in the fireplace, sell roof slates for vodka.

FIELD NOTES, NIZHNEANGARSK, DECEMBER 2012

This conversation excerpt provided a quick image of the Evenkis without the responsibility of specificity, and irrespective of practice. There is a need for a note here that unlicensed logging is illegal in Russia. Thus an Evenki woman from a nearby Evenki community also addressed the issue, showing how far from practice the stereotypes might be:

In our village, there are many single mothers. We make our living as we can. Even firewood is so hard to buy; it is so expensive. We live in a forest, and firewood cost a fortune! ... We try to buy firewood or exchange on fish ... You have to feed family — at least you have to buy bread, tea, and some grains .... In Nizhneangarsk there are different kinds of payments that you have to pay for kindergarten. Apart from the payments for the kindergarten itself, there are monthly exactions for equipment, toys.... If you cannot afford these payments, you are taken on control (postavit' na kontrol'); your children can be taken from you to an orphanage.... Relatives help a lot— to buy firewood, to chop it ...

INTERVIEW, NEARBY EVENKI COMMUNITY, DECEMBER 2012

Thus, as is shown above, in Nizhneangarsk there is a clear perception of two different social categories - the 'Russians' and the Evenkis-with different social positioning. Being an Evenki is perceived as an essentialist identity coalesced around an image of inferiority, driven not only by structural and ideological interpellation, but also by local stereotypes. The processes of interpellation make the Russian identity desirable, while the Evenki identity is best distanced from. These identity categories are perceived in similar ways to the cultural constructs of the 'Orient' and the 'Occident', and more precisely according to the ideas of European identity as superior, rational, developed and humane over Asiatic identity as inferior, backward, ill-mannered and aberrant (Said 2003). These constructions serve not only as a basis for differentiation between people, but justification of this differentiation, and consequently, discrimination.

Some of the adolescents express feelings of being second-rate and victims of discrimination. As one of the male Evenki adolescents remembered: 'I don't 
feel particularly proud to be Evenki. When I was a small child, Russian adolescents used to call me names: "tungus", etc.' In another interview a 14-year-old Evenki girl from a mixed Evenki-Buryat family confided: 'Inside the school and outside, on the streets, the Russian kids often call me names. During my childhood, I did not take it as offensive, but now it's hard for me'. Another Evenki 14-year-old girl even stated: 'They [Russian adolescents] call us, me and my sister, names. Sometimes I think we are enemies'; then her 13-year-old sister continued: 'Sometimes I am so angry when they call us names, I want to hurt them' (Interviews, Nizhneangarsk, 2016). Faced with such attitudes, some Evenki adolescents who lack facial features typically associated with northern Indigenous peoples can deny or hide their Evenki identity. The 14-yearold Anton, officially registered as an Evenki, for instance, defined himself as a Jew, not only '[b]ecause my father is a Jew', but also '[b] ecause I do not look like Evenki'. There are other examples when adolescents from Nizhneangarsk claimed to be Russians or stated that they do not know their or their parents' ethnicity, as they said: 'Maybe Russians', despite Evenki roots and official status.

The dynamics of denial of ethnicity not only demonstrate the ethnic hierarchies in the region that distinguish between worthy and unworthy social positions, but also provide examples of internalising existing stereotypes by Evenki adolescents. The adolescents' conscious representations of who they are in relation to others could be seen as their attempts to negotiate their identities in the context of existing rigid classifications of races and ethnicities, provided by others. The possibility of the shift from one ethnic identity to another points at the non-essentialist, constructed nature of these classifications.

Thus, in spite of these rigid classifications in practice, the ethnic and racial differences are fluid, and socially constructed in the community of the research. Hence I claim that, for many interviewed adolescents, while they were trying to bridge the practice and articulated 'knowledge', or what they had learnt, ethnicity became a construction and could be used as a strategy.

\section{Managing Identities}

In Nizhneangarsk, racial and ethnic discrimination based on differences in phenotype and perceived behaviour gave rise to a phenomenon of denial of identity. Some Evenki adolescents, that lack the phenotypic characteristics associated with Siberian Natives, present themselves as ethnically Russian. 'Managing' one's identity this way offers the adolescents a possibility to escape negative, stigmatising racial and cultural stereotypes imposed on them by virtue of their membership of an Indigenous group. That could be regarded as a 
survival strategy. It is certainly a response to oppression, a liberating and resistance strategy resulted from a system of power relations and discrimination of indigenous groups in this region. However, this strategy is only possible to those who, because of their looks, are not immediately categorised as Evenkis by the inhabitants of Nizhneangarsk.

While many non-Evenki informants pointed at behavioural differences between the Evenkis and non-Evenkis, moving to Russian ethnic identity does not require any behavioural changes. In Nizhneangarsk, the hegemonic and privileged position of the ethnic Russians ensures that the disreputable behaviour of some ethnic Russian residents would neither constitute their exclusion from the group nor be regarded as a mark of Russianness. According to local standards, disreputable behaviour includes, among others, excessive alcohol consumption, violence and use of offensive language. Many ethnically Russian young people do consume alcohol and use offensive language and can show violent behaviour. Violent behaviour is often related to alcohol consumption in Russia in general (wH O 2006). However, locally, disreputable behaviour among ethnic Russians is usually explained by their class, educational level, social or personal problems, but never by their ethnic origins, while in the case of the Evenkis it is always pointed at as a stereotypical ethnic attribute. I can conclude that in this particular locality the strategy of managing identities is imperfect regarding normalisation of models of behaviour. However, it is perfect in terms of not only state integrity goals, but also ensuring the privilege mark of Russianness, making Russianness a desirable objective also on a personal level.

In practice to move from Evenki to Russian ethnic identity requires one only to look Russian, or is a matter of skin colour and shape of 'cheeks' and eyes. Here I should underline that Nizhneangarsk is comprised of both phenotypic and non-phenotypic Evenkis. That is, the strategy of 'managing' ethnic identities is not accessible to everyone, since the category 'Russian' is identified in Buryatia with 'Europeoid' race. Thus, being a liberating and resistance strategy for 'Russian-looking' ones, it becomes the reinforcement of oppression for other 'Evenki-looking' Evenki adolescents, who cannot or do not want to use the strategy. Bhabha (1994) underlined that, in relationships of oppression, the colonised internalises the image dictated by the coloniser. It signifies that a person has undergone a process of assimilation and develops self-consciousness based on their perceptions of how they are viewed by others (Hoe 2011). Assimilation is indeed a mission of Soviet policies as well as falling in line with patriotic missions of the local school and the local museum. Thus, by deploying the strategy, adolescents that lack Native features accept 
the perceived stereotypical traits of Evenki identity or internalise the racist stereotypes of others about the Evenkis. By imitating the coloniser, the adolescents not only internalise and maintain the ideology of others towards the Evenkis, but also accomplish victimisation of themselves and other Evenkis. Therefore, by using the strategy of managing identities, adolescents not only try to escape, but also accept the discrediting attributes of stigmatised identity, or labels, placed by others, and thereby re-construct the Evenki identity.

Hence, the strategy of 'managing' ethnic identities is a liberating strategy and a way of achieving higher social status. It also serves as a means to create and maintain ethnic hierarchies. Moreover, in Severobaikalskii district of Buryatia, Evenki adolescents' identities could be viewed as an image of the self that is seen through the mirrors of Western/European culture in the sense of defining what is beautiful, what is outdated and what is civilised. Consequently, Evenki adolescents often try to avoid Evenki cultural practices or being associated with Evenkis. Most of them do not participate in the Evenki cultural centre's activities. In most interviews, Evenki adolescents underlined the European standards of beauty. Even some of the Evenki-registered teenagers ridiculed Evenki looks. The strategy of managing identities is also closely related to attributions of shame, as moral judgements and stigmatising stereotypes are imposed on Evenkis. Thus, an Evenki woman acknowledged:

In Nizhneangarsk in school Evenki children are ashamed to be Evenkis.

Or, in another case an Evenki woman acknowledged:

We lost our dignity.... We are not proud to be the Evenki....

Then, regarding the questions of relations of domination and the position of the Evenkis in these relationships, she continues:

We have lost our rights to our land and other natural resources. To fish, we have to ask for permission, to hunt we have to ask for permission.

FIELD NOTES, DECEMBER 2012

Orna Sasson-Levy and Avi Shoshana argue that 'shame arises when one is forced, by taking the roles of (significant or generalised) others, to see that they do not accept the idealised self-image that one has built up' (SassonLevy \& Shoshana 2013: 464). However, the passages from the interview also point at losing dignity in the face of lost rights to self-determination and 
self-government. Thereby, shame acts as both a social control mechanism and at the same time a concession to the demand for conformity.

Furthermore, the residents, irrespective of ethnicity, are commenting on a shift to Russian ethnic identity as unscrupulous, and even as a betrayal of culture and ancestors. For instance, one of the Evenki adolescents stated:

Some of the Evenkis claim that they are Russians. I consider such behaviour as disgusting.

NIZHNEANGARSK, INTERVIEW, 2016

The individuals practising the strategy are expected to feel ashamed also at their acts of concealment of their ethnic origins. Therefore maintaining the strategy of managing identities is censured locally and places individuals exercising the strategy into a two-fold sense of shame, over both their ethnic origin and concealment of that origin.

The reverse shift in identities is also possible: that is, a conscious choice of some ethnic Russians to pass as Evenkis, playing on imprecise phenotype characteristics of Evenkis. However, the motive of some Russian families to identify themselves and/or their children as Evenki is not to become Evenki or escape a stigmatised identity, but to use gaps in the legislation and more importantly the lack of indigenous self-governance. This situation is certainly considered by many Evenki as another injustice, used by some people and reinforced by the state. For instance, Varia, a local woman, who claims that in such a small village people know each other, and each others' relatives, argues:

I do not know how they managed to register themselves as Evenki, but we know that they are not. They claim that they are Evenkis and then record their children as the Evenkis and that everything just to receive entitlements ... They already know that it is possible to enter the universities using the Evenki quotas ... But real Evenki children are mainly from disadvantaged families, and they do not go to study.

FIELD NOTES, NIZHNEANGARSK, DECEMBER 2012

The perceptions of marginalisation vary with the position or status of parents of the adolescents. The adolescents with parents of higher social status, often associated with education, occupation or financial success, have higher aspirations in their life, higher self-esteem and more clear plans for their future. It is also interesting here that in such families, children have greater support for further education and in general parents provide advice and stronger parental 
support to children. For instance, from an interview with an adolescent with parents of higher social status:

Interviewer: In your opinion are the Evenki different from other nationalities?

Boris: In my opinion all people are individuals. They are all different. We are all people. I do not see any difference between ethnicities. [...] I participate in the Evenki cultural centre activities. I dance there. In summer we conduct the Evenki religious rituals. But, in general, I am participating not for just having fun, but supporting the Evenki traditions. $[\ldots]$

I: What do you want to do in the future?

B: I want to go to Krasnoiarsk to study in Medical University. I want to become a dentist. My parents, my mother is an Evenki, and my father is Buryat, encourage me to study further. They say how important it is. [Interview, Nizhneangarsk, December 2012]

The perception of marginalisation is lower among adolescents from highstatus families. It could be explained by the fact that adolescents with higher status have higher self-esteem and more possibilities in life, making 'managing' identities unnecessary. However, the same adolescent expressed his aesthetic preferences, based on European standards of beauty, which most of the Evenki adolescents do not fit. While the status of parents can be a guarding factor against discrimination and marginalisation, this interview shows that the adolescent internalises the existing standards of beauty, which leads to self-marginalisation and marginalisation of other Evenkis. Nonetheless, the cases of pride of belonging to Evenki culture were marginal. I interviewed over 20 Evenki-registered adolescents. Only two of them expressed willingness to know more about their cultural roots. Both of them came from local professionals' families or higher-status families.

The process of marginalisation reduces the choices available to many adolescents in the community to fulfil their aspirations. While the status of 'Evenki' entitles to certain social benefits, which is again more important for the poorer population, the stereotypes about Evenkis provide a 'spoiled identity' (Goffman 1984), which one should escape to gain social privileges or esteem. Although in Severobaikalskii district there are Evenki families with better income and higher status as local professionals (such as a doctor, a nurse, teachers), most adolescents came from families living on low incomes, able to exercise almost no control over the administration and future of their community. These families often cannot support children in higher educational institutions. When 
other possibilities are closed for many Evenki adolescents, a higher status could be achieved through 'managing' identities, reinforcing the established hierarchies.

The strategy of 'managing' ethnic identity, employed by many Evenki adolescents in Nizhneangarsk, is the product of the social-political context, formed during the periods of Tsarist Russia and the Soviet Union and reinforced by contemporary Russia. The strategy is a product of racist stereotypes and ideologically created racialised meanings, such as primitive, outdated, and poor. The strategy operates as a shaming interpellation. The ideologically created nature of Evenkis is perceived not only by Russians, but also by Evenki adolescents, who are often ashamed to be Evenki. At the same time, through museums and schools, the state effectively promotes an appealing alternative: to become a member of an advanced and strong society, to view themselves as Russian citizens.

\section{Acknowledgement}

The fieldwork for this paper carried out in 2016 was supported by Oskar Öflunds Stiftelse sr.

\section{References}

\section{Official Documents}

RF (Russian Federation). 2000a. Federal Law on General Principles for Organization of Communes of Indigenous Peoples of the North, Siberia and the Far East of the Russian Federation of 20 July 2000 No. 104-FZ. Available at: http://base.garant $. r u / 182356 /$ (accessed 9 July 2017).

RF (Russian Federation). 20oob. RF Government Decree about the Unified List Indigenous Small-Numbered Peoples of the Russian Federation of 24 March 2000 No. 255. Available at: http://base.garant.ru/181870/\#block_1000 (accessed 9 July 2017).

RF Constitution, Article 69. 2009. http://www.constitution.ru/10003000/10003000-5 .htm (accessed 9 July 2017).

Russian Census. 1989. [Vsesoiuznaia perepis' naseleniia].http://demoscope.ru/weekly/ ssp/rus89_regi.php (accessed 10 July 2017).

Russian Census 2002. http://demoscope.ru/weekly/ssp/ruso2_regı.php (accessed 10 July 2017).

Russian Census. 2010. http://www.gks.ru/free_doc/new_site/perepis2010/croc/perepis _itogi1612-tom4.htm (accessed 10 July 2017). 
UssR Census. 1926. [Vsesoiuznaia perepis' naseleniia]. http://demoscope.ru/weekly/ ssp/rus_26.php?reg=444 (accessed 10 July 2017).

USSR Census. 1970. [Vsesoiuznaia perepis' naseleniia]. http://demoscope.ru/weekly/ ssp/rus70_regi.php (accessed 10 July 2017).

Severobaikalskii Municipal District Official Website. http://sb-rayon.ru/o-rajone/ istoriya-rajona.html (accessed 27 July 2017).

\section{Works Cited}

Arefiev, A.L. 2014. Language of the Indigenous Minorities of the North, Siberia and the Far East in Educational System: Past and present. Moscow: Social Forecasting and Marketing Center.

Bartels, D. \& A. Bartels. 1995. When the North was Red: Aboriginal education in Soviet Siberia. Montreal: McGill-Queen's University Press.

Bashkuev, V. 2013. Silencing the shame: forgetting of the 1920s syphilis epidemic in Buryat-Mongolia as a strategy of post-Soviet identity construction. Jefferson Journal of Science and Culture (3): 110-32.

Bhabha, H.K. 1994. The Location of Culture. London: Routledge.

Bhabha, H.K. 2013. Nation and Narration. New York (NY): Routledge.

Bisher, J. 2006. White Terror: Cossack warlords of the Trans-Siberian. London: Routledge.

Bloch, A. 2004. Red ties and Residential Schools: Indigenous Siberians in a post-Soviet state. Philadelphia (PA): University of Pennsylvania Press.

Davydov, V. 2008. Natsionalnaia Evenkiiskaia Derevnia Na Severnom Baikale: Soprotivlenie Dominiruyschemu Diskursu [National Evenki village in the north Baikal: resistance to the dominant discourse]. Zhurnal Sotsiologii I Sotsial'Noi Antropologii $9(3): 146-63$.

Eidheim, H. [1969] 1982. When ethnic identity is a social stigma, in F. Barth (ed.), Ethnic Groups and Boundaries. The Social Organization of Culture Difference: 39-57. Oslo: Universitetsforlaget.

Fondahl, G. 1998. Gaining Ground? Evenkis, land and reform in southeastern Siberia. Boston (MA): Allyn \& Bacon.

Goffman, E. [1963] 1984. Stigma: Notes on the management of spoiled identity. Harmondsworth: Penguin.

Grant, B. 1993. Siberia hot and cold: reconstructing the image of Siberian indigenous peoples, in G. Diment \& Y. Slezkine (eds.), Between Heaven and Hell: The myth of Siberia in Russian culture: 227-254. New York (NY): St Martin's Press.

Hoe, N.D. 2011. Review of Others in Mind: Social Origins of Self-Consciousness by Phillipe Rochat. Anthropology and Education Quarterly 42: 306-7.

Kozlov, A., G. Vershubsky \& M. Kozlova. 2007. Indigenous Peoples of Northern Russia: Anthropology and health. Raahe: International Association of Circumpolar Health Publishers. 
Landers, B. 2011. Empires Apart: A History of American and Russian imperialism. New York (NY): Pegasus Books.

Pasechnik V.V., A.A. Kamenskii \& G.G. Shvetsov. 2010. Biologia 8 klass: Uchebnik dlia Obscheobrazovatel'nih Uchrezhdenii [Biology 8th Grade: School Text Book for Education Institutions]. Moscow: Prosveschenie.

Remnev, A.V. \& N.G. Suvorova. 2010. Upravliaemaia Kolonizatsia i Stihiinye Migratsionnye Protsessy Na Aziatskih Okrainah Rossiiskoi Imperii: Otsenki i Prognozi Imperskih Ekspertov [Controlled Colonization and Spontaneous Migration Processes on the Asian Outskirts of the Russian Empire: Estimates and Forecasts of Imperial Experts], in V.I. Diatlov (ed.) Migratsii $i$ Diaspori v Sotsiokulturnom, Politicheskom i Economicheskom Prostranstve Sibiri. Rubezhi XIX-XX i XX-XXI Vekov [Migration and diaspora in the socio-cultural, political and economic space of Siberia. Frontiers of the XIX-XX and XX-XXI centuries]: 17-64. Irkutsk: Ottisk.

Said, E.W. 2003. Orientalism: Western conceptions of the Orient. London: Penguin.

Sasson-Levy, O. \& A. Shoshana. 2013. 'Passing' as (non)ethnic: the Israeli version of acting White. Sociological Inquiry 83(3): 448-72.

Slezkine, Y. 1994. Arctic Mirrors: Russia and the small peoples of the north. Ithaca (NY): Cornell University Press.

Shubin, A.S. 2001. Evenki Pribaikal'a [Baikal Evenkis]. Ulan-Ude: Belig.

Shubin, A.S. 2007. Evenki. Ulan-Ude: Respublikanskaia Tipografia.

Ulturgasheva, O. 2012. Narrating the Future in Siberia: Childhood, adolescence and autobiography among the Eveny. New York (NY): Berghahn Books.

Vasilevich, G.M. \& A.V. Smolyak. 1964. The Evenks, in M.G. Levin \& L.P. Popatov (eds.), The Peoples of Siberia: 620-54. Chicago (IL): University of Chicago Press.

WHO. 2006. Interpersonal violence and alcohol in the Russian Federation. Policy Briefing. Available online: http://www.euro.who.int/_data/assets/pdf_file/oo11/98804/ E88757.pdf. 